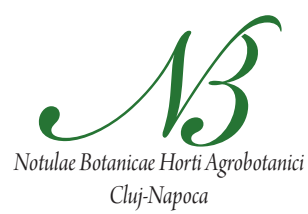

\title{
Some Fruit Characteristics of Iranian Cornelian Cherries (Cornus mas L.)
}

\author{
Hamid HASSANPOUR*, Yousef HAMIDOGHLI, Habibollah SAMIZADEH
}

Guilan University, Agricultural Faculty, Rasht, Iran; phhassanpour@gmail.com (*corresponding author)

\begin{abstract}
Although the Cornelian Cherry is widely grown in the north-eastern areas of Iran, it is not recognized as an important fruit crop as are many other fruit species. Large variability has been observed in all morphological and chemical compositions under study. Fruit weight varied from 1.499 to $3.29 \mathrm{~g}$, whereas seed weight ranged from 0.249 to $0.425 \mathrm{~g}$. The average lengths of fruits were between 15.22 and $22.31 \mathrm{~mm}$, and the average widths of them were between 10.26-16.3 mm. The content of ascorbic acid ranged from 240-360 mg/ $100 \mathrm{~g}$ fresh weight. The total soluble solids and total acidity were 5-12.5\% and 0.43-1.86\% respectively. Grouping of Cornelian Cherry accessions based on 5 factors was performed and were divided into three sub-clusters. The results obtained from this study might be helpful for Cornelian Cherry breeders trying to develop new genotypes and varieties.
\end{abstract}

Keywords: correlation, nutritional properties, physical properties, principle component

\section{Introduction}

Cornus (belongs to the family Cornaceae) is a very large genus which comprises forty species of shrubs and trees native to Central and Southern Europe and parts of Western Asia. Most species are ornamentals. Only a few species are grown for their fruits, chief among which is the Cornelian Cherry (Cornus mas L.) (Brindza et al., 2007; Ercisli, 2004b). It is a deciduous shrub, or small tree, from 5 to 8 $\mathrm{m}$ high and grows up to an altitude of $1400 \mathrm{~m}$ (Klimenko, 2004; Otakar et al., 2010). Iran has great agricultural potential because each region of the country can support the cultivation of different kinds of crops.

In Iran, Cornelian Cherry trees are spread in east parts of the country (East Azerbaijan and Qazvin provinces). In these regions, 99\% of Cornelian Cherry crop is harvested from open pollinated seedlings of wild genotypes. Because the plants are open pollinated, they vary widely in terms of productivity and fruit characteristics, such as size, shape, color, flavor and nutritional value. The high genetic diversity obtained from seed multiplication of Cornelian Cherry for centuries. Thorough evaluation of the genetic resources of the native genotypes is essential for selecting most useful genotypes for future breeding programs designed to introduce traits such as hardiness and disease resistance from wild genotypes into cultivated varieties (Ercisli et al., 2008).

Consumer interest in health foods has increased market demand for high quality fruits such as the Cornelian Cherry (Ercisli, 2004b). Cornelian Cherry cultivation is slowly growing throughout the world, not only because it bears delicious and nutritious fruits, but also because it is an attractive ornamental plant, and is among the first to blossom in spring (Ercisli, 2004b). The fruit is olive shaped, 10-20 mm, pink, yellow or red external colour and, in general, sweet-sour taste (Yilmaz et al., 2009a). The fruits are very valuable for fresh consumption and for processing to produce syrups, juices, and jam (Brindza et al., 2007) spirits and other traditional products (Otakar et al., 2010). Fruits, leaves, flowers and bark are utilized in traditional and modern medicine to cure many disorders (Ercisli, 2004a; Seeram et al., 2002). The astringent fruit is a good treatment for bowel complaints and fevers, and also used in the treatment of cholera. The flowers of this plant are used in the treatment of diarrhoea (Demir and Kalyoncu, 2003). Fresh Cornelian Cherry fruits contain twice as much ascorbic acid (vitamin C) as oranges. Furthermore, fruits are rich in anthocyanins, organic acids and tannins (Hassanpour et al., 2011; Sara et al., 2008; Seeram et al., 2002; Tural and Koca, 2008). The Cornelian Cherry is becoming a more popular crop because of recent advances in breeding superior varieties which have an attractive colour, low tannin content, and high sugar content (Brindza et al., 2007; Karadeniz, 2002). Studies by Guleryuz et al. (1996) revealed that the characteristics of the fruit ranged from 2.907 to 3.906 for fruit weights, 5.950 to 10.707 for flesh/ seed ratio, $11.5 \%$ to $16.8 \%$ for TSS, 43.78 to $76.75 \mathrm{mg}$ vitamin C per $100 \mathrm{~g}, 2.215 \%$ to $4.690 \%$ for total acidity (as malic acid), 3.0242 to 7.168 TSS/acid ratio, 4.220 to 9.960 for sugar and $2.024 \%$ to $5.664 \%$ for reducing sugar, respectively. Also Cornelian Cherry wood, because of its hardness, is used in the production of furniture, jewels, musical instruments and various hand-crafted products (Brindza et al., 2007).

Therefore, detailed information about the health-promoting components of more Cornelian Cherry genotypes could lead to a better understanding and an increased consumption of this fruit, including its use in functional foods 
248

and as ingredients in pharmaceuticals, nutraceuticals, and medicine.

The objective of this study was to provide information on the status of the genetic resources of the Cornelian Cherry in Iran; its distribution in different parts of the country, and of the characteristics and uses of selected accessions.

\section{Materials and methods}

A total of 20 Cornelian Cherry (Cornus mas L.) accessions were used in this study. These accessions were selected from Horand (C1-C10) and Kalibar (C11-C20) regions in East Azerbaijan. Approximately $2 \mathrm{~kg}$ of ripe Cornelian Cherry fruits per accession were harvested from trees. The fruits were selected according to their uniformity of shape and colour and then transported to the laboratory for further analysis. In totality, 50 fruits in mature status per accession were evaluated for their weight $(\mathrm{g})$, length $(\mathrm{mm})$, width $(\mathrm{mm})$ and other important traits. Fruit juice was analyzed to determination of ascorbic acid, total acidity (TA), total solid content (TSS) and pH. Fruit and Seed weight $(\mathrm{g})$ were measured by a digital balance with a sensitivity of $0.001 \mathrm{~g}$ (Scaltec Company, Gottingen, Germany; model SPB31). Fruit length (mm), fruit width $(\mathrm{mm})$, stone width $(\mathrm{mm})$ and stone length $(\mathrm{mm})$ were measured by using a digital vernier caliper with a sensitivity of 0.01 $\mathrm{mm}$ (Demir and Kalyoncu, 2003). Flesh/seed ratio (FSR) was calculated by mean fruit weight-mean seed weight/ mean seed weight. TSS was determined by refrectometry of one drop extracted juice of each fruit at $22^{\circ} \mathrm{C}$ (Kyoto Electronics Manufacturing Co. Ltd., Japan, and Model RA-250HE).TA was determined by diluting each $2 \mathrm{ml}$ aliquot of fruit juice in $20 \mathrm{ml}$ of distilled water and then titrated to $\mathrm{pH} 8.2$ by using 0.1 molar $\mathrm{NaOH}$. The $\mathrm{pH}$ value was indicated by $\mathrm{pH}$ meter (HBJ-260).

\section{Extraction and measurement of total ascorbic acid}

Total ascorbic acid content was determined by the dinitrophenylhydrazine (DNPH) method (Terada et al., 1978). Five grams of homogenized fruit tissue was added to $100 \mathrm{~mL}$ of a mixture of $6 \%$ metaphosphoric acid in $2 \mathrm{~mol}$ $\mathrm{L}^{-1}$ acetic acid. The mixture was centrifuged at $17000 \times g$ for $15 \mathrm{~min}$ at $4^{\circ} \mathrm{C}$ and the supernatant was filtered through Whatman filter paper. One millilitre aliquot of the supernatant was mixed with $0.05 \mathrm{~mL}$ of $0.2 \%$ 2, 6-dichlorophenolindolphenol (DCIP) and the solution was incubated at room temperature for $1 \mathrm{~h}$. After that, $1 \mathrm{~mL}$ of $2 \%$ thiourea in $5 \%$ metaphosphoric acid and $0.5 \mathrm{~mL}$ of $2 \% \mathrm{DNPH}$ in $4.5 \mathrm{~mol} \mathrm{~L}^{-1}$ sulfuric acid were added to the solution, and then incubated at $60^{\circ} \mathrm{C}$ for $3 \mathrm{~h}$. The reaction was stopped by placing the tubes in an ice bath and slowly adding 2.5 $\mathrm{mL}$ of cold $90 \%$ sulfuric acid. Total ascorbic acid was measured by absorbance at $540 \mathrm{~nm}$ using a standard curve. The concentrations were expressed as ascorbic acid on a fresh weight basis, $\mathrm{mg}$ per $100 \mathrm{~g}$ of fruit.

\section{Statistical analysis}

Data were subjected to analysis of variance and means were separated by Duncan's multiple range test at $p<0.01$ significance level by SAS (Software Version 9.1 SAS). Correlation between the traits was determined using the Pearson correlation coefficient. Relationships among the accessions were investigated by factor analysis. Correlation and factor analysis were performed by SPSS (Software Version 16 SPSS). Scatter plots of the first 2 factors were created with SPSS (Software Version 16 SPSS) as well. Cluster analysis was done to yield a dendrogram depicting the morphological relatedness of the Cornelian Cherry accessions by SPSS (Software Version 16 SPSS).

\section{Results and discussion}

\section{Nutritional properties}

The nutritional properties of Cornelian Cherry fruits are given in Tab. 1. TSS values of these 20 accessions ranged from $5 \%$ to $12.5 \%$. This value was reported as $2.1 \%$ to $24.1 \%$ in previous studies (Demir and Kalyoncu, 2003; Ercisli, 2004b; Pantelidis et al., 2007; Pirlak et al., 2003; Rudkovsky, 1960; Yilmaz et al., 2009a). The observed variation could be as a result of different environmental conditions and accession types, since TSS is greatly influenced by these factors (Demir and Kalyoncu, 2003).

The ascorbic acid content varied from 240 to 360 $\mathrm{mg} / 100 \mathrm{~g}$ while the other studies showed that it can be ranged from 12.6 to $122 \mathrm{mg} / 100 \mathrm{~g}$ (Demir and Kalyoncu,

Tab. 1. Chemical properties of the Iranian accessions of Cornelian Cherry fruit

\begin{tabular}{|c|c|c|c|c|c|c|}
\hline $\begin{array}{l}\text { Name of } \\
\text { samples }\end{array}$ & $\begin{array}{l}\text { TSS } \\
{[\%]}\end{array}$ & TA & $\begin{array}{c}\text { TSS/TA } \\
\text { ratio }\end{array}$ & $\mathrm{PH}$ & $\begin{array}{l}\text { Vitamin C } \\
{[\mathrm{mg} / 100 \mathrm{~g}]}\end{array}$ & $\begin{array}{c}\text { Altitude } \\
{[\mathrm{m}]}\end{array}$ \\
\hline $\mathrm{Cl}$ & $10 \mathrm{~d}$ & $1.28 \mathrm{f}$ & $7.81 \mathrm{i}$ & $3.12 q$ & $324 d$ & 980 \\
\hline $\mathrm{C} 2$ & $6.5 \mathrm{q}$ & $0.93 \mathrm{j}$ & $6.99 \mathrm{k}$ & $3.38 \mathrm{e}$ & $312 \mathrm{e}$ & 1034 \\
\hline $\mathrm{C} 3$ & $8.1 \mathrm{j}$ & $1.28 \mathrm{f}$ & $6.33 n$ & $3.36 \mathrm{~g}$ & $240 n$ & 1024 \\
\hline C4 & $10.5 \mathrm{c}$ & $1.28 \mathrm{f}$ & $8.20 \mathrm{~h}$ & $3.51 b$ & $354 b$ & 1039 \\
\hline C5 & $9.7 \mathrm{e}$ & $1.71 \mathrm{c}$ & $5.67 \mathrm{o}$ & $3.28 \mathrm{k}$ & $306 f$ & 1025 \\
\hline C6 & $9.1 \mathrm{~g}$ & $1.83 \mathrm{~b}$ & $4.97 \mathrm{r}$ & $3.07 \mathrm{r}$ & $276 \mathrm{i}$ & 1018 \\
\hline C7 & 6.90 & $1.01 \mathrm{~h}$ & 6.831 & $3.29 \mathrm{j}$ & $312 \mathrm{e}$ & 1065 \\
\hline C8 & $8.5 \mathrm{i}$ & $0.75 \mathrm{~m}$ & $11.33 \mathrm{~d}$ & $3.31 \mathrm{~h}$ & 2521 & 1275 \\
\hline C9 & 7.51 & $1.17 \mathrm{~g}$ & $6.41 \mathrm{~m}$ & 3.271 & $360 \mathrm{a}$ & 919 \\
\hline $\mathrm{C} 10$ & $10 \mathrm{~d}$ & $1.28 \mathrm{f}$ & $7.81 \mathrm{i}$ & $3.22 \mathrm{~m}$ & $330 \mathrm{c}$ & 1278 \\
\hline C11 & $6.8 \mathrm{p}$ & $0.96 \mathrm{i}$ & $7.08 \mathrm{j}$ & $3.47 \mathrm{c}$ & $300 \mathrm{~g}$ & 1469 \\
\hline $\mathrm{C} 12$ & $9.6 f$ & $1.86 \mathrm{a}$ & $5.16 \mathrm{q}$ & $3.2 \mathrm{n}$ & $294 \mathrm{~h}$ & 1511 \\
\hline $\mathrm{C} 13$ & $11.1 \mathrm{~b}$ & $0.74 n$ & $15 b$ & $3.37 \mathrm{f}$ & $246 \mathrm{~m}$ & 1483 \\
\hline $\mathrm{C} 14$ & $9.7 \mathrm{e}$ & $1.01 \mathrm{~h}$ & $9.60 \mathrm{f}$ & $3.4 \mathrm{~d}$ & 2521 & 1450 \\
\hline $\mathrm{C} 15$ & $7.1 \mathrm{~m}$ & $1.33 \mathrm{e}$ & $5.34 p$ & 3.180 & $276 \mathrm{i}$ & 1266 \\
\hline $\mathrm{C} 16$ & $8 \mathrm{k}$ & $0.96 \mathrm{i}$ & $8.33 \mathrm{~g}$ & $3.13 p$ & $360 \mathrm{a}$ & 1061 \\
\hline $\mathrm{C} 17$ & $8.7 \mathrm{~h}$ & $0.85 \mathrm{k}$ & $10.24 \mathrm{e}$ & 3.271 & $276 \mathrm{i}$ & 986 \\
\hline $\mathrm{C} 18$ & $5 r$ & 0.430 & $11.63 \mathrm{c}$ & $3.95 \mathrm{a}$ & $246 \mathrm{~m}$ & 903 \\
\hline C19 & $12.5 \mathrm{a}$ & 0.81 & $15.63 \mathrm{a}$ & $3.30 \mathrm{i}$ & $264 \mathrm{k}$ & 1220 \\
\hline $\mathrm{C} 20$ & $7 \mathrm{n}$ & $1.49 \mathrm{~d}$ & $4.7 \mathrm{~s}$ & $3.29 \mathrm{j}$ & $270 \mathrm{j}$ & 1223 \\
\hline
\end{tabular}

Values in the same column with different lower-case letters are significantly different at $p<0.01$. 
Tab. 2. Physical properties of the Iranian accessions of Cornelian Cherry fruit

\begin{tabular}{|c|c|c|c|c|c|c|c|c|c|c|}
\hline $\begin{array}{l}\text { Name of } \\
\text { samples }\end{array}$ & $\begin{array}{l}\text { Fruit } \\
\text { weight } \\
(\mathrm{g}) \\
\end{array}$ & $\begin{array}{l}\text { Seed } \\
\text { weight } \\
(\mathrm{g}) \\
\end{array}$ & $\begin{array}{l}\text { Flesh } \\
\text { weight } \\
(\mathrm{g}) \\
\end{array}$ & $\begin{array}{c}\text { Flesh/stone } \\
\text { Ratio }\end{array}$ & $\begin{array}{c}\text { Fruit } \\
\text { length } \\
(\mathrm{mm}) \\
\end{array}$ & $\begin{array}{l}\text { Fruit } \\
\text { width } \\
(\mathrm{mm}) \\
\end{array}$ & $\begin{array}{c}\text { Index } \\
\text { (Fruit Length/ } \\
\text { Fruit width) } \\
\end{array}$ & $\begin{array}{l}\text { Stone } \\
\text { length } \\
(\mathrm{mm}) \\
\end{array}$ & $\begin{array}{l}\text { Stone } \\
\text { width } \\
(\mathrm{mm})\end{array}$ & $\begin{array}{c}\text { Index } \\
\text { (Stone length/ } \\
\text { stone width) }\end{array}$ \\
\hline $\mathrm{C} 1$ & $3.29 \mathrm{a}$ & $0.347 \mathrm{~g}$ & $2.94 a$ & $8.48 \mathrm{~b}$ & $22.31 \mathrm{a}$ & $16.3 a$ & $1.37 \mathrm{~d}$ & $12.56 n$ & $6.36 \mathrm{k}$ & $1.97 \mathrm{k}$ \\
\hline $\mathrm{C} 2$ & $2.220 \mathrm{~h}$ & 0.2991 & $1.92 \mathrm{f}$ & $6.42 \mathrm{f}$ & $19.62 b$ & $13.8 \mathrm{e}$ & $1.42 b$ & $13.46 \mathrm{~h}$ & 6.6h & $2.04 \mathrm{e}$ \\
\hline C3 & $2.331 \mathrm{e}$ & $0.345 \mathrm{~h}$ & $1.99 \mathrm{~d}$ & $5.76 \mathrm{i}$ & $18.32 \mathrm{e}$ & $14.18 \mathrm{c}$ & $1.29 \mathrm{~g}$ & $13.28 \mathrm{i}$ & $6.76 \mathrm{~g}$ & 1.961 \\
\hline $\mathrm{C} 4$ & $2.145 \mathrm{k}$ & $0.325 \mathrm{j}$ & $1.82 \mathrm{~g}$ & $5.6 \mathrm{j}$ & $18.16 \mathrm{~g}$ & $13.66 \mathrm{ef}$ & $1.33 \mathrm{f}$ & $13.22 \mathrm{j}$ & $6.94 \mathrm{de}$ & $1.90 \mathrm{p}$ \\
\hline C5 & $2.346 \mathrm{e}$ & $0.345 \mathrm{~h}$ & $2.001 \mathrm{~d}$ & $5.8 \mathrm{~h}$ & 17.361 & $13.48 \mathrm{gh}$ & $1.29 \mathrm{~g}$ & $12.74 \mathrm{~m}$ & $6.62 \mathrm{~h}$ & $1.92 \mathrm{o}$ \\
\hline C6 & $2.24 \mathrm{~g}$ & $0.279 \mathrm{n}$ & $1.96 \mathrm{e}$ & $7.03 \mathrm{~d}$ & $17.16 \mathrm{~m}$ & $13.4 \mathrm{~h}$ & $1.28 \mathrm{~g}$ & $12.22 p$ & 6.120 & $2.00 \mathrm{j}$ \\
\hline C7 & $2.367 \mathrm{~d}$ & $0.249 \mathrm{~s}$ & $2.12 \mathrm{~b}$ & $8.51 \mathrm{a}$ & $19.02 \mathrm{c}$ & $14.4 \mathrm{~b}$ & $1.32 \mathrm{f}$ & $12.2 p$ & $6.24 \mathrm{~m}$ & $1.95 \mathrm{~m}$ \\
\hline C8 & 1.6710 & $0.262 \mathrm{q}$ & $1.41 \mathrm{~m}$ & $5.38 \mathrm{k}$ & $17.12 \mathrm{n}$ & $12.46 \mathrm{jk}$ & $1.37 \mathrm{~d}$ & $12.22 \mathrm{p}$ & $6.08 \mathrm{p}$ & $2.00 \mathrm{~h}$ \\
\hline C9 & 1.4990 & $0.251 \mathrm{r}$ & $1.25 \mathrm{o}$ & $4.97 \mathrm{~m}$ & $15.22 \mathrm{~s}$ & $12.76 \mathrm{i}$ & $1.19 \mathrm{~h}$ & $11.64 \mathrm{q}$ & $6.4 \mathrm{j}$ & $1.82 \mathrm{r}$ \\
\hline $\mathrm{C} 10$ & $1.541 \mathrm{p}$ & $0.282 \mathrm{~m}$ & $1.26 \mathrm{no}$ & $4.46 \mathrm{p}$ & $15.92 \mathrm{q}$ & $12.08 \mathrm{l}$ & $1.32 \mathrm{f}$ & $12.32 \mathrm{o}$ & 6.31 & $1.95 \mathrm{~m}$ \\
\hline C11 & 1.9981 & $0.416 c$ & $1.58 \mathrm{j}$ & $3.80 \mathrm{~s}$ & $17.56 \mathrm{k}$ & $12.56 \mathrm{j}$ & $1.4 \mathrm{c}$ & $14.94 \mathrm{a}$ & $7.14 b$ & $2.09 \mathrm{c}$ \\
\hline C12 & $2.272 \mathrm{f}$ & $0.361 \mathrm{f}$ & $1.91 \mathrm{f}$ & 5.291 & $18.12 \mathrm{~h}$ & $13.38 \mathrm{~h}$ & $1.35 \mathrm{e}$ & $14.22 \mathrm{c}$ & $6.84 f$ & $2.08 \mathrm{~d}$ \\
\hline C13 & $2.202 \mathrm{i}$ & $0.422 b$ & $1.78 \mathrm{~h}$ & $4.22 q$ & $18.24 \mathrm{f}$ & $12.88 \mathrm{i}$ & $1.42 \mathrm{~b}$ & $14.5 \mathrm{~b}$ & $7.5 \mathrm{a}$ & $1.93 n$ \\
\hline C14 & $2.420 \mathrm{c}$ & $0.343 \mathrm{i}$ & $2.08 \mathrm{c}$ & $6.06 \mathrm{~g}$ & $18.36 \mathrm{~d}$ & $13.32 \mathrm{~h}$ & $1.38 \mathrm{~d}$ & $13.64 \mathrm{~g}$ & $6.38 \mathrm{jk}$ & $2.14 \mathrm{~b}$ \\
\hline C15 & $2.164 j$ & $0.266 p$ & $1.9 \mathrm{f}$ & $7.14 \mathrm{c}$ & $17.6 \mathrm{j}$ & $13.62 \mathrm{fg}$ & $1.29 \mathrm{~g}$ & $13.76 \mathrm{f}$ & $6.16 n$ & $2.23 \mathrm{a}$ \\
\hline C16 & $2.458 \mathrm{~b}$ & $0.319 \mathrm{k}$ & $2.14 \mathrm{~b}$ & $6.71 \mathrm{e}$ & $17.88 \mathrm{i}$ & $13.98 \mathrm{~d}$ & $1.28 \mathrm{~g}$ & $12.7 \mathrm{e}$ & $6.56 \mathrm{e}$ & $1.94 \mathrm{f}$ \\
\hline $\mathrm{C} 17$ & $1.965 \mathrm{~m}$ & $0.425 a$ & $1.54 \mathrm{k}$ & $3.62 t$ & $16.32 p$ & $12.3 \mathrm{k}$ & $1.33 \mathrm{f}$ & $14.06 \mathrm{e}$ & $6.92 \mathrm{e}$ & $2.03 \mathrm{f}$ \\
\hline C18 & 1.9901 & $0.356 \mathrm{e}$ & $1.63 \mathrm{i}$ & $4.59 \mathrm{o}$ & $15.52 \mathrm{r}$ & $10.26 \mathrm{n}$ & $1.51 \mathrm{a}$ & 13.001 & $6.96 \mathrm{~d}$ & $1.87 \mathrm{q}$ \\
\hline C19 & $1.554 \mathrm{p}$ & $0.271 \mathrm{o}$ & $1.28 \mathrm{n}$ & $4.73 n$ & $16.32 p$ & $11.56 \mathrm{~m}$ & $1.41 \mathrm{~b}$ & $13.14 \mathrm{k}$ & $6.48 \mathrm{i}$ & $2.03 \mathrm{~g}$ \\
\hline C20 & $1.892 \mathrm{n}$ & $0.390 \mathrm{~d}$ & $1.50 \mathrm{l}$ & $3.85 \mathrm{r}$ & $16.68 \mathrm{o}$ & $12.42 \mathrm{jk}$ & $1.34 \mathrm{e}$ & $14.16 \mathrm{~d}$ & $7.06 \mathrm{c}$ & $2.00 \mathrm{i}$ \\
\hline
\end{tabular}

Values in the same column with different lower case letters are significantly different at $p<0.01$

2003; Ercisli, 2004b; Otakar et al., 2010; Pantelidis et al., 2007; Pirlak et al., 2003; Yilmaz et al., 2009a, 2009b). Similar results were found by Hassanpour et al. (2011). The ascorbic acid content of this study were generally higher than the previous findings (Demir and Kalyoncu, 2003; Ercisli, 2004b; Otakar et al., 2010; Pantelidis et al., 2007; Pirlak et al., 2003; Yilmaz et al., 2009a, 2009b). In addition, their ascorbic acid content was higher than other fruits known for their elevated ascorbic acid content, such as strawberries and oranges (46-31 mg per $100 \mathrm{~g}$ ) (Roberts and Gordon, 2003) and kiwi fruits (29-80 mg per $100 \mathrm{~g}$ ) (Nishiyama et al., 2004).

In this research, titrable acidity varied from $0.43 \%$ to $1.86 \%$, while it was ranged from $0.62 \%$ to $4.69 \%$ in other studies (Demir and Kalyoncu, 2003; Yilmaz et al., 2009a, 2009b). TSS/TA ratio ranged from 4.7 to 15.63 while it has been reported between 6.37 and 12.61 by Demir and Kalyoncu (2003).

\section{Physical properties}

The fruit, seed and flesh weight, flesh/stone ratio, fruit length, fruit and stone width and stone length, of the studied accessions are given in Tab. 2. There were statistical differences in terms of fruit, seed and flesh weight, flesh/stone ratio, fruit length, fruit and stone width and stone length of among accessions (Tab. 2). Average fruit weight values of Cornelian Cherry accessions ranged from $1.499 \mathrm{~g}$ (accession C9) to $3.29 \mathrm{~g}$ (accession C1). The seeds weight were varied from $0.249 \mathrm{~g}$ (accession C7) to $0.425 \mathrm{~g}$ (accession C17); flesh weight from $1.25 \mathrm{~g}$ (accession C9) to $2.94 \mathrm{~g}$ (accession 1); Flesh/stone Ratio from 3.62 (accession C17) to 8.51 (accession C7); Fruit length from $15.22 \mathrm{~mm}$ (accession C9) to $22.31 \mathrm{~mm}$ (accession C1); fruit width from $10.26 \mathrm{~mm}$ (accession C18) to $16.3 \mathrm{~mm}$ (accession C1); stone length from $11.64 \mathrm{~mm}$ (accession C9) to $14.94 \mathrm{~mm}$ (accession C11); stone width from 6.08 $\mathrm{mm}$ (accession C8) to $7.5 \mathrm{~mm}$ (accession C13).

The average fruit weights reported by others ranged from 0.55 to $9.2 \mathrm{~g}$ in Turkey, Slovakia and Serbia (Brindza et al., 2009; Demir and Kalyoncu, 2003; Ercisli, 2004b; Pirlak et al., 2003; Sandra et al., 2010; Turhan et al., 2007; Yilmaz et al., 2009a, 2009b). One of the significant breeding goals for the Cornelian Cherry is to have larger fruits and attractive fruit characteristics such as flesh/seed ratio, taste etc. (Demir and Kalyoncu, 2003). Therefore, it could be suggested that future breeding program should be primarily focused on fruit weight increase, as a characteristic that has the highest direct correlation with mesocarp weight (Bijelic et al., 2007).

Average flesh/seed ratio was varied from 3.62 to 8.51 . However, this value was reported to be between 2.05 to 12.62 in Turkey and Serbia (Demir and Kalyoncu, 2003; Ercisli, 2004b; Pirlak et al., 2003; Sandra et al., 2010; Turhan et al., 2007; Yilmaz et al., 2009b). The result indicates that the fruit types used in this study were within normal limits.

In the selected accessions, fruit length and width varied from 15.22 to $22.31 \mathrm{~mm}$ and 10.26 to $16.3 \mathrm{~mm}$, respec- 
Tab. 3. Correlation coefficients among physical properties in Cornelian Cherry genotypes

\begin{tabular}{ccccccccccc}
\hline Variable & 1 & 2 & 3 & 4 & 5 & 6 & 7 & 8 & 9 & 10 \\
\hline 1-Fruit weight & 1 & $0.24^{\mathrm{ns}}$ & $0.99^{* *}$ & $0.68^{* *}$ & $0.87^{* *}$ & $0.8^{\mathrm{ns}}$ & $0.03^{\mathrm{ns}}$ & $0.13^{\mathrm{ns}}$ & $0.02^{\mathrm{ns}}$ & $0.16^{\mathrm{ns}}$ \\
2-Seed weight & - & 1 & $0.09^{\mathrm{ns}}$ & $-0.53^{* *}$ & $0.08^{\mathrm{ns}}$ & $-0.13^{\mathrm{ns}}$ & $0.38^{* *}$ & $0.75^{* *}$ & $0.83^{* *}$ & $0.03^{\mathrm{ns}}$ \\
3-Flesh weight & - & - & 1 & $0.77^{* *}$ & $0.88^{* *}$ & $0.83^{* *}$ & $-0.02^{\mathrm{ns}}$ & $0.03^{\mathrm{ns}}$ & $-0.9^{\mathrm{ns}}$ & $0.16^{\mathrm{ns}}$ \\
4-Flesh/stone Ratio & - & - & - & 1 & $0.68^{* *}$ & $0.78^{* *}$ & $-0.25^{\mathrm{ns}}$ & $-0.42^{* *}$ & $-0.59^{* *}$ & $0.14^{\mathrm{ns}}$ \\
5-Fruit length & - & - & - & - & 1 & $0.86^{* *}$ & $0.11^{\mathrm{ns}}$ & $0.09^{\mathrm{ns}}$ & $-0.07^{\mathrm{ns}}$ & $0.22^{\mathrm{ns}}$ \\
6-Fruit width & - & - & - & - & - & 1 & $-0.41^{* *}$ & $-0.09^{\mathrm{ns}}$ & $-0.24^{\mathrm{ns}}$ & $0.15^{\mathrm{ns}}$ \\
7-index & - & - & - & - & - & - & 1 & $0.33^{* *}$ & $0.35^{* *}$ & $0.06^{\mathrm{ns}}$ \\
8-Stone length & - & - & - & - & - & - & - & 1 & $0.74^{* *}$ & $0.52^{* *}$ \\
9-Stone width & - & - & - & - & - & - & - & - & 1 & $-0.18^{\mathrm{ns}}$ \\
\hline 10-index & - & - & - & - & - & - & - & - & - & 1 \\
\hline${ }^{* * *}:$ Correlation coefficient is significant at $p<0.05$ and $p<0.01$ respectively. ns: Non-significant. & & & & &
\end{tabular}

Tab. 4. Eigen values and cumulative variance for 5 factors resulted from factor analysis

\begin{tabular}{cccccc}
\hline \multicolumn{7}{c}{ Component } \\
\hline & 1 & 2 & 3 & 4 & 5 \\
\hline Fruit weight & $0.964^{* *}$ & -0.058 & 0.151 & 0.033 & -0.028 \\
\hline Seed weight & 0.066 & 0.144 & $0.938^{* *}$ & 0.073 & 0.000 \\
\hline Flesh weight & $0.977^{* *}$ & -0.079 & 0.018 & 0.023 & -0.031 \\
\hline Flesh/stone Ratio & $0.777^{* *}$ & -0.148 & $-0.565^{* *}$ & 0.009 & -0.092 \\
\hline Fruit length & $0.950^{* *}$ & 0.013 & 0.032 & 0.077 & 0.101 \\
\hline Fruit width & $0.865^{* *}$ & -0.399 & -0.119 & -0.058 & 0.113 \\
\hline Index & 0.043 & $0.832^{* *}$ & 0.274 & 0.215 & -0.098 \\
\hline Stone length & 0.031 & 0.038 & $0.832^{* *}$ & 0.463 & -0.009 \\
\hline Stone width & -0.084 & 0.185 & $0.935^{* *}$ & -0.182 & -0.015 \\
\hline Index & 0.149 & -0.162 & 0.023 & $0.918^{* *}$ & -0.005 \\
\hline TSS & 0.041 & -0.049 & 0.019 & -0.018 & $0.966^{* *}$ \\
\hline TA & 0.156 & $-0.867^{* *}$ & -0.010 & 0.049 & 0.053 \\
\hline Vitamin C & 0.157 & -0.453 & -0.123 & $-0.602^{* *}$ & 0.003 \\
\hline TSS/TA & -0.153 & $0.831^{* *}$ & 0.043 & -0.059 & 0.479 \\
\hline pH & -0.242 & $0.710^{* *}$ & 0.268 & -0.188 & -0.427 \\
\hline Eigen value & 5.295 & 3.268 & 1.988 & 1.418 & 1.376 \\
\% of variance & 35.297 & 21.789 & 13.256 & 9.452 & 9.172 \\
Cumulative & 35.297 & 57.086 & 70.341 & 79.793 & 88.965 \\
variance \% & & & & & \\
\hline
\end{tabular}

${ }^{* *}$ Significant factor loading (values above 0.50$)$.

tively while in other similar studies it ranged from 12.05 to $29.9 \mathrm{~mm}$ and 7.43 to $23.51 \mathrm{~mm}$, respectively. The actual values is dependent on the experiment region (Brindza et al., 2009; Demir and Kalyoncu, 2003; Ercisli, 2004b; Pirlak et al., 2003; Sandra et al., 2010; Turhan et al., 2007; Yilmaz et al., 2009b). The accession C9 with the lowest shape index value (1.19) had the most round fruit. The highest fruit shape index was found in the accession C18 (1.51) with longest fruit, while in other similar studies the fruit shape index ranged from 1.18 to 2.35 (Demir and Kalyoncu, 2003; Sandra et al., 2010; Turhan et al., 2007).

Average seed length and width varied from 11.64 to $14.94 \mathrm{~mm}$ and 6.08 to $7.5 \mathrm{~mm}$, respectively while Brindza et al. (2009) has reported that seed length and width was between 10.16 and $15.49,5.14$ and 7.10 for Cornelian
Cherry. The accession C18 had the most round seed, or the lowest seed shape index value (1.87). The highest seed shape index, (the longest seed) was found in the accession C15 (2.23).

The variation of fruit weight, seed weight, flesh/stone ratio, fruit length, fruit width, TSS, $\mathrm{pH}, \mathrm{TA}$ and ascorbic acid contents in Cornelian Cherry fruits could be result of heterozygote nature of seed propagated accessions and the effect of different environmental conditions where the accessions grown. The analyses of the physicochemical characteristics of Cornelian Cherry accessions in this work demonstrated that the twenty accessions are different in terms of their fruit weight, seed weight, flesh/stone ratio, fruit length, fruit width, and TSS, $\mathrm{pH}$, TA and ascorbic acid contents. The accession $\mathrm{C} 1$ had high fruit weight, fruit length, fruit width and flesh weight. The other promising accessions are $\mathrm{C} 9$ for its less stones length, $\mathrm{C} 8$ for its less stones width, $\mathrm{C} 13$ for its smaller stones, higher TSS content, TSS/TA ratio and TA content, C18 for its for higher $\mathrm{pH}$ and accession $\mathrm{C} 16$ for its higher ascorbic acid content. These six accessions may be especially useful in developing cultivars with greater agronomic potential.

Correlation coefficient for different physical parameters showed that significant positive correlations existed among most of the traits (Tab. 3). There were significant positive correlations between fruit weight, flesh weight, flesh/stone ratio and fruit length; seed weight, stone length and width $(p<0.01)$, whereas a significant negative correlation existed between seed weight and flesh/stone ratio; flesh/stone ratio and stone length, stone width $(p<0.01)$. It was observed that there was no apparent correlation between fruit weight and fruit width. Therefore, it is not possible to sort out Cornelian Cherry trees with weighted fruits according to the fruit width.

Factor analysis showed that the first fifth Principle component explained 35, 22, 13, 9.5 and $9 \%$ of the variation respectively, making a total of $89 \%$ (Tab. 4). Among the studied variables tested, the fruit weight, flesh weight, flesh/stone ratio, fruit width and length, were highly correlated with factor 1 . The highly correlated variables with factor 2 were TSS/TA and $\mathrm{pH}$. The highest correlation with factor 3 was calculated from seed weight, seed width 


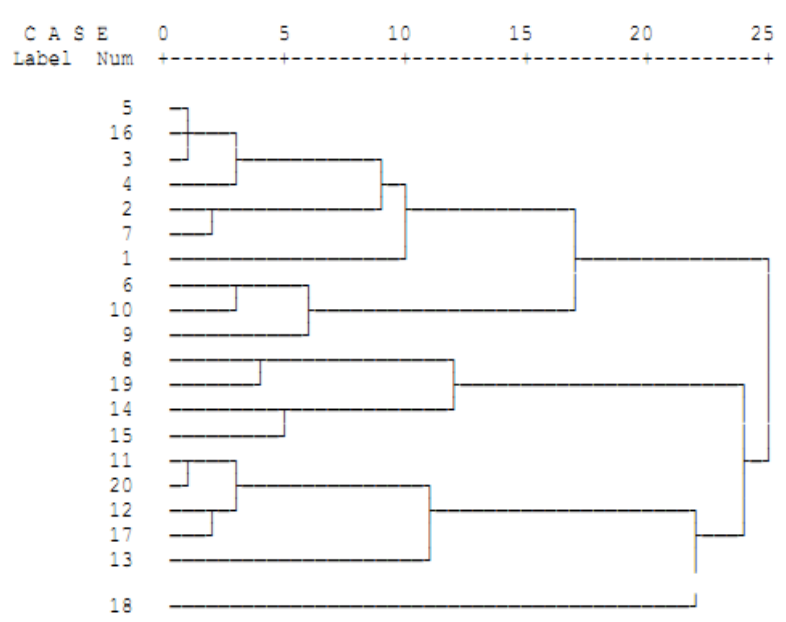

Fig. 1. Dendrogram of grouping 20 Cornelian Cherry accessions based on 5 main factors and Ward's method

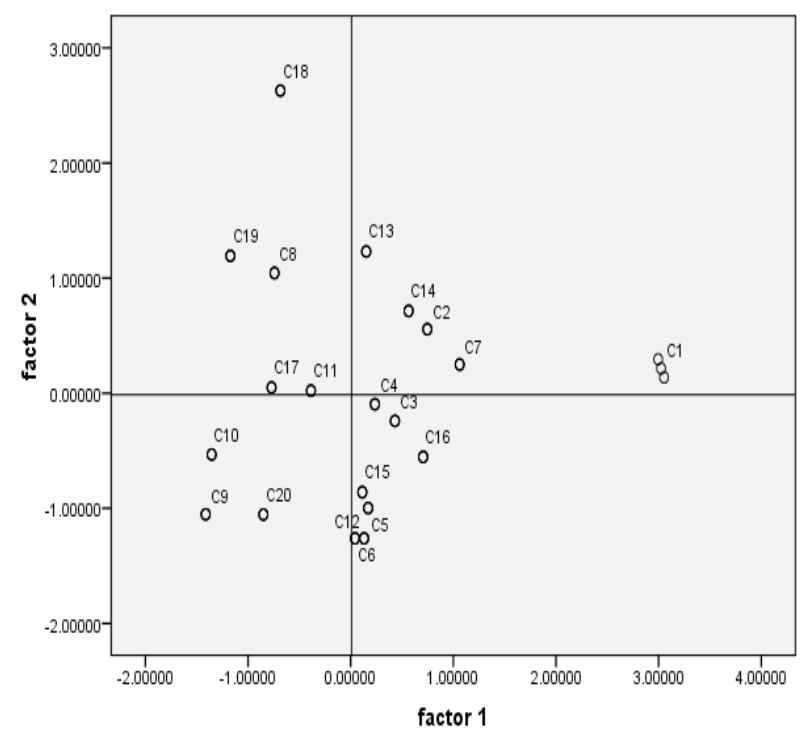

Fig. 2. Factor analysis plot of the first two factors depicting relationship among Cornelian Cherry (cornus mas) accessions established in Iran

and length. The highest correlation with factor 5 was calculated from TSS. The vitamin C was negatively correlated with factor 4 . While TSS/TA and $\mathrm{pH}$ was positively correlated with factor 2 , TA was negatively correlated with factor 2. The PC analysis of Yilmaz et al. (2009b) study in Turkey indicated that the first three PC explained $61 \%$ of the total variation. Grouping of Cornelian Cherry accessions based on these 5 factors was performed and accessions in distance of 22 were divided into three sub-clusters (Fig. 1).

The distribution of accessions on the factor 1 and factor 2 plots is showed in Fig. 2. Starting from the negative to the positive values of factor 1 , the accessions indicated a general increase in the fruit flash weight, length and width, and a decrease in seed weight. Starting from the negative towards the positive values of factor 2 , the accessions were characterized by a large seed. The factor analysis provided a simplified classification of the Cornelian Cherry accessions for collection and for breeding. The scatter plot (Fig. 2) also shows geometrical distances among the accessions in the plot that reflect a similarity among them in terms of variables measured. Three groups of related accessions were separated. Group A includes those accessions with a low negative value of factor 1 and intermediate of factor 2 (C9, C10, C11, C17 and C20). Group B consists of seven accessions that corresponded with a high negative factor 2 and a low positive factor 1 value $(\mathrm{C} 3, \mathrm{C} 4, \mathrm{C} 5, \mathrm{C} 6, \mathrm{C} 12$, $\mathrm{C} 15$ and $\mathrm{C} 16)$. Four accessions that have an intermediate positive factor 1 and 2 value are in the third, $\mathrm{C}$ group, of related accessions (C2, C7, C13 and C14). For further collection it is sufficient to take just one accession from each of these groups. Based on the position, a small genetic distance is observed between $\mathrm{C} 8$ and $\mathrm{C} 19$ accessions. The $\mathrm{C} 1$ accession can be considered unique. This accession characterized by the large fruit size and small seed size. This is the first report on genetic diversity among Cornelian Cherry accessions in Iran based on morphological markers. As a tool for germplasm biodiversity description, we have used principal component analysis to study correlations among variables and establish relationship among accessions. This method is commonly applied for characterization of biodiversity of genetic resources in such studies (Sarkhosh et al., 2009; Yilmaz et al., 2009b).

\section{Conclusions}

This investigation clearly indicates that wide biodiversity occurred among Cornelian Cherry accessions. Fruits differ among themselves in the weight, length, width, ascorbic acid, TSS and TA, etc. The results of the study are helpful for understanding the variability and attempting the selection of superior desirable Cornelian Cherry accessions for bringing to commercial cultivation.

\section{References}

Bijelic S, Ninic-Todorovic J, Jacimovic G, Golosin B, Cerovic S, Vidicki B (2007). Morphometric fruit traits of selected Cornelian Cherry genotypes. Contemp Agric 56(6):130137.

Brindza P, Brindza J, Toth D, Klimenko SV, Grigorieva O (2009). Biological and Commercial Characteristics of Cornelian Cherry (Cornus mas L.) Population in the Gemer Region of Slovakia. Acta Hort 818:85-94.

Brindza P, Brindza J, Toth D, Klimenko SV, Grigorieva O (2007). Slovakian Cornelian Cherry (Cornus mas L.): Potential for cultivation. Acta Hort 760:433-437.

Demir F, Kalyoncu IH (2003). some nutritional, pomological and physical properties of Cornelian Cherry (Cornus mas L.). J Food Eng 60:335-341. 
252

Ercisli S (2004a). A short review of the fruit germplasm resources of Turkey. Genet Resour Crop Evol 51:419-435.

Ercisli S (2004b). Cornelian Cherry germplasm resources of Turkey. J Fruit Ornam Plant Res 12:87-92.

Ercisli S, Orhan E, Esitken A, Yildirim N, Agar G (2008). Relationships among some Cornelian Cherry genotypes (Cornus mas L.) based on RAPD analysis. Genet Resour Crop Evol 55:613-618.

Guleryuz M, Bolat I, Prrlak L (1996). Selection of table Cornelian Cherry (Cornus mas L.) types in Coruh Valley. Turk J Agric For 22:357-364.

Hassanpour H, Hamidoghli Y, Hajilo J, Adlipour M (2011). Antioxidant capacity and phytochemical properties of Cornelian Cherry (Cornus mas L.) genotypes in Iran. Sci Hortic 129:459-463.

Karadeniz T (2002). Selection of native Cornelian Cherries grown in Turkey. J Am Pomol Soc 56(3):164-167.

Klimenko S (2004). The Cornelian Cherry (Cornus mas L.) collection, preservation and utilization of genetic resources. J Fruit Ornam Plant Res 12:93-98.

Nishiyama I, Yamashita Y, Yamanaka M, Shimohashi A, Fukuda T, Oota T (2004). Varietal difference in vitamin C content in the fruit of kiwifruit and other Actinidia species. J Agr Food Chem 52:5472-5475.

Otakar R, Jiri M, Daniela K, Tunde J (2010). Selected cultivars of Cornelian Cherry (Cornus mas L.) as a new food source for human nutrition. Afr J Biotechnol 9(8):1205-1210.

Pantelidis GE, Vasilakakis M, Manganaris GA, Diamantidis G (2007). Antioxidant capacity, phenol, anthocyanin and ascorbic acid contents in raspberries, blackberries, red currants, gooseberries and Cornelian Cherries. Food Chem 102:777-783.

Pirlak L, Guleryuz M, Bolat I (2003). Promising Cornelian Cherries (Cornus mas L.) from the Northeastern Anatolia region of Turkey. J Am Pomol Soc 57(1):14-18.

Roberts WG, Gordon MH (2003). Determination of the total antioxidant activity of fruit and vegetables by a liposome assay. J Agr Food Chem 51:1486-1493.
Rudkovsky GP (1960) Cornelian Cherry in the Ukraine priroda. Plant Breed Abstr 30:4218

Sandra B, Branislava G, Jelena Ninic T, Slobodan C (2010). Morphological characteristics of best Cornelian Cherry (Cornus mas L.) genotypes selected in Serbia. Genet Resour Crop Evol 71:1190-1197.

Sara T, Bruno M, Franco C, Stefano B, Jules B, Chris D, Ezra C, Arnaud B, Maurizio B (2008). Antioxidants, Phenol Compounds, and Nutritional Quality of Different Strawberry Genotypes. J Agr Food Chem 56:696-704.

Sarkhosh A, Zamani Z, Fatahi R, Ranjbar H (2009). Evaluation of genetic diversity among Iranian soft-seed pomegranate accessions by fruit characteristics and RAPD markers. Sci Hortic 121:313-319.

Seeram N, Schutzki R, Chandra R, Nair MG (2002). Characterization, quantification and bioactivities of anthocyanins in Cornus species. J Agr Food Chem 50:25192523.

Terada M, Watanabe Y, Kunitomo M, Hayashi E (1978). Differential rapid analysis of ascorbic-acid and ascorbic-acid 2-sulfate by dinitrophenylhydrazine method. Anal Biochem 84:604-608.

Tural S, Koca I (2008). Physicochemical and antioxidant properties of Cornelian Cherry friuts (Cornus mas L.) grown in Turkey. Sci Hortic 116:362-366.

Turhan K, Ilkay T, Yunus P (2007). Drying characteristics and heat energy require of Cornelian Cherry fruits (Cornus mas L.).J Food Eng 78:735-739.

Yilmaz KU, Ercisli S, Zengin Y, Sengul M, Kafkas EY (2009a). Preliminary characterisation of Cornelian Cherry (Cornus mas L.) genotypes for their physicochemical properties. Food Chem 114:408-412.

Yilmaz KU, Zengin Y, Ercisli S, Orhan E, Yalcinkaya E, Taner O, Erdogan A (2009b). Biodiversity, exositu conservation and characterization of Cornelian Cherry (Cornus mas L.) genotypes in Turkey. Biotechnol Biotechnol Eq 23(1):11431149. 